\title{
MODEL PEMBELAJARAN MASTERY LEARNING PADA MATA PELAJARAN MATEMATIKA MATERI BANGUN DATAR SISWA KELAS III
}

\author{
Oleh \\ Annisa Jannah Setyowati'), Heri Setiyawan ${ }^{2)}$ \& Endang Nuryasana ${ }^{3)}$ \\ 1,2,3 Universitas Wijaya Kusuma Surabaya \\ 1annisa.jannah04031997@gmail.com , 2heri.setiyawan_fbs@uwks.ac.id \& \\ 3endang.nuryasana58@gmail.com
}

\begin{abstract}
Abstrak
Proses belajar mengajar di sekolah kebanyakan memakai metode ceramah yang membuat siswa cepat jenuh dan tidak aktif saat pembelajaran. Oleh karena itu peserta didik tidak mudah menerima pelajaran dengan baik dan proses pembelajaran tidak menapai indikator yang sudah ditentukan. Maka dari itu dengan diterapkannya model pembelajaran yang menarik membuat siswa aktif dalam pembelajaran dan siswa merasa tidak jenuh. Model pembelajaran mastery learning jarang dipakai oleh kebanyakan guru. Model mastery learning atau belajar tuntas ini model yang menerapkan belajar kelompok agar pembelajaran dapat tuntas sesuai dengan indikator yang dicapai dan siswa tidak merasa bosan dalam proses pembelajaran dikelas. Tujuan dilakukannya penelitian ini untuk menyusun perangkat model pembelajaran Mastery Learning pada mata pelajaran Matematika materi bangun datar siswa kelas III. Metode penelitian yang digunakan adalah kualitatif. Alat pengumpulan data yang digunakan oleh peneliti adalah lembar validasi yang terdiri dari RPP, LKS, dan Tes Hasil Belajar. Lembar validasi tersebut dinilai berdasarkan pada aspek kevalidan data. Apabila hasil kevalidan data melebihi kriteria kelayakan yaitu 81,0\%, maka lembar validasi tersebut dapat dinyatakan valid dan layak digunakan pada siswa kelas III.
\end{abstract}

Kata Kunci: Mastery Learning, Matematika, Bangun Datar \& Siswa

\section{PENDAHULUAN}

Berdasarkan Undang-Undang Nomor 20

Tahun 2003, pengertian dari pendidikan merupakan suatu bentuk kemampuan seseorang yang secara sadar dan terencana supaya dapat menciptakan kegiatan dan proses pembelajaran. Hal ini diharapkan agar seseorang tersebut secara langsung dapat mengembangkan potensi diri, masyarakat, bangsa dan negara. Sehingga, dengan adanya hal tersebut maka sangat diperlukan peranan tenaga pendidik yang ahli, seperti guru pengajar yang ada di lingkungan sekolah dasar dan menengah, serta dosen yang ada di perguruan tinggi. Penguasaan ilmu pengetahuan dan keterampilan guru atas materi-materi pada mata pelajaran seharusnya memiliki keterkaitan dengan ilmu pengetahuan kependidikan khusus, saah satunya metodik khusus dan praktik keguruan (Syah M. 2010: 231). Salah satu mata pelajaran yang diharapkan mampu dikuasi oleh seorang pengajar yaitu matematika.

Berdasarkan peraturan pada

Permendiknas No. 22 Tahun 2006 (dalam Soviawati 2011: 80), pelajaran matematika harus diperkenalkan kepada semua peserta didik. Siswa siswi yang masih berada di sekolah bisa menjadi langkah awal bagi para tenaga pendidik untuk meningkatkan keahlian mereka dalam berpikir yang logic, analitic, systematic, critics, dan creative. Sehingga, untuk meningkatkan kemampuan tersebut, maka para siswa siswi perlu meningkatkan kemampuan mereka pada pelajaran matematika. Hanya saja, karakteristik mata pelajaran tersebut memiliki objek yang bersifat abstrak. Sehingga, hal itulah yang menjadi salah satu alasan banyaknya peserta didik merasa sulit memahami pelajaran matematika (Soviawati, 2011:80).

Masalah matematika yang umum dijumpai pada siswa menurut Hasratuddin 
(2008:69) kurangnya minat siswa-siswi pada mata pelajaran matematika yang sering kita tahu adalah rendahnya daya pikir siswa, atau kurangnya bakat siswa dalam berhitung, inilah yang membuat proses belajar mengajar yang kurang baik dan tidak kondusif serta pelajaran matematika belum seutuhnya didasari atas kemampuan dan keinginan siswa-siswi sendiri. Sedangkan menurut Soviawati (2011:80), prestasi siswa dalam mata pelajaran matematika masih kurang baik karena salah satu tujuan keberhasilan siswa dilihat pada pencapaian Nilai Ebtanas Murni (NEM) atau Nilai Ujian Akhir Nasional (NUAN). Mata pelajaran matematika masih dianggap bagi sebagian peserta didik sebagai mata pelajaran yang sulit dan merasa takut untuk mempelajari matematika. Oleh karena itu, masalah dalam pelajaran matematika dapat disajikan dalam bentuk kelompok dengan menggunakan model mastery learning atau belajar tuntas. Apabila model pembelajaran tersebut diterapkan untuk memahami mata pelajaran matematika, maka diharapkan akan dapat meningkatkan kemampuan peserta didik dalam memahami materi dengan baik serta dapat dijadikan sebagai kebutuhan dalam kehidupan seharihari.

Menurut Hasna (2011), belajar tuntas (mastery learning) merupakan suatu penerapan pembelajaran yang mensyaratkan siswa-siswi untuk menguasai hampir semua materi pelajaran yang diajarkan sekolah. Apabila diterapkan dengan baik, maka model tersebut diharapkan mampu meningkatkan hasil belajar bagi para peserta didik. Hal ini disebabkan bahwa pada model tersebut terdapat sejumlah kegiatan yang akan dilakukan siswa sehingga terbentuknnya suasana belajar yang aktif dan beberapa kegiatan tambahan. Sedangkan mastery learning menurut Suryasubroto (2002: 104), terdapat program perbaikan dan program pengayaan yang tidak ada pada pembelajaran konvensional. Program perbaikan ini diberikan kepada siswa yang belum memahami penjelasan materi, sedangkan program pengayaan atau pendalaman materi diberikan kepada siswa yang telah memahami materi pelajaran. Kedua program ini diberikan agar siswa yang memiliki beda bakat dalam penguasaan materi sama-sama bisa memahami materi dalam masa yang sama dan bisa meningkatkan hasil belajarnya. Materi yang digunakan dalam model pembelajaran mastery learning adalah materi bangun datar.

Menurut Rahmadini (2012:19) materi utama yang harus dipelajari oleh siswa-siswi Sekolah Dasar salah satunya yaitu mempelajari tentang bangun datar. Hal ini perlu dipelajari bagi peserta didik karena dalam menjelaskan tentang sifat bangun datar dapat diterapkan pada kehidupan sehari-hari. Sehingga, apabila peserta didik mampu mempelajari dengan baik, maka diharapkan dapat menghubungkan sifat bangun datar dengan lingkungan sekitar.

Rumusan masalah dalam penelitian ini yaitu kevalidan perangkat model pembelajaran Mastery Learning pada mata pelajaran Matematika Materi Bangun Datar siswa kelas III. Tujuan dilakukannya pada penelitian ini untuk menyusun perangkat model pembelajaran Mastery Learning pada mata pelajaran Matematika materi bangun datar siswa kelas III. Adapun manfaat penulisan adalah agar penyusunan perangkat ini diharapkan dapat mencapai suatu pembelajaran lebih efektif dan efisien. Adapun batasan masalah dalam penulisan ini hanya berfokus pada penyusunan perangkat model pembelajaran mastery learning pada mata pelajaran matematika materi bangun datar siswa kelas III, perangkat model pembelajaran pada penelitian ini divalidasi ahli oleh 5 (lima) orang, dan juga materi yang digunakan adalah persegi dan persegi panjang.

\section{LANDASAN TEORI}

Belajar merupakan hal penting didalam pendidikan. Dalam proses pembelajaran sering kali mendapatkan arti luas yang berkaitan dengan adanya pendidikan. Dengan ini, maka arti belajar dalam pendidikan adalah penelitian dan percobaan dalam tingkah laku oleh pendidik yang ditujukan untuk pencapaian 
pengetahuan yang lebih luas dan mengalami perubahan dalam diri pendidik (Syah, 2010:93). Selain itu menurut Syah (2010: 87) belajar merupakan suatu hal yang mendasar dalam menyelenggarakan setiap pembelajaran dalam suatu proses belajar mengajar. Dengan demikian keberhasilan atau ketidakberhasilan dalam mencapai suatu proses pembelajaran tidak lepas dari adanya belajar, baik dialami peserta didik di sekolah ataupun dilingkungan sekitar.

Dari beberapa para ahli membuat dan merumuskan definisi dari "belajar" dan hampir semua definisi berbeda antara para hali satu dengan yang lainya. Pandangan beberapa ahli tentang belajar dalam Verika (2015), yakni sebagai berikut: (a) Belajar menurut Ernest $\mathrm{H}$. Higlard berpendapat jika orang melakukan belajar maka orang itu sudah melakukan tindakan yang telah dilakukannya dan mencoba untuk mengevaluasi serta mempelajari bagaimana caranya untuk menghadapi tindakan yang telah orang tersebut lakukan. (b) Belajar menurut Noehi Nasution berpendapat bahwa perubahannya seseorang merupakan bentuk hasil dari keseriusan dan ketentuan dalam belajar, kegagalan dalam belajar bukan disebabkan akibat adanya kematangan atau perubahan sementara. (c) Winkel berpendapat bahwa belajar merupakan sekumpulan kegiatan yang dilakukan oleh seseorang, baik secara berpikir ataupun tingkah laku yang berinteraksi langsung dengan lingkungannya sehingga akan menimbulkan perubahan dalam knowledge, understanding, skill, dan attitude. (d) Belajar menurut Snelbecker berpendapat bahwa belajar seharusnya berisikan tentang pemahaman dan wawasan terkait perilaku biasa sampai yang tidak biasa. (e) Belajar menurut Whiterington berpendapat bahwa sebuah proses perubahan kepribadian dan diwujudkan dalam bentuk penguasaan tingkah laku yang baru sehingga akan menghasilkan perubahan skill, habit, dan attitude. Bahwa dapat di simpulkan definisi belajar ialah terjadinya suatu perubahan didalam kehidupan seseorang dan merupakan suatu wujud meningkatnya kualitas dan kuantitas sikap seperti meningkatnya pemahaman, sikap, pengetahuan, pemahaman, kebiasaan, daya pikir, keterampilan dan kemampuan lainnya.

Istilah pembelajaran menurut Gagne \& Briggs, 1979 (dalam Khodijah, 2019: 175) yaitu "instruction", artinya usaha untuk membantu seseorang dalam belajar. Sedangkan menurut Gagne 1997 (dalam Khodijah, 2019: 175) mengartikan bahwa pembelajaran adalah serangkaian dari peristiwa yang bersifat eksternal dan dikonsepkan untuk dapat membantu beberapa proses pembelajaran yang bersifat internal. Selain itu, Miarso dalam Khodijah (2019: 175) berpendapat bahwa belajar adalah suatu proses perubahan yang ada pada diri seseorang. Pembelajaran bisa dikatakan sebagai suatu usaha yang dilakukan oleh para tenaga pengajar supaya siswa siswi mampu mendapatkan hasil belajar yang maksimal. Pembelajaran tidak harus dilakukan secara resmi seperti disekolah, namun dapat dilakukan secara tidak resmi seperti dirumah dan di lingkungan masyarakat. Tugas pembelajaran disekolah sudah menjadi tanggungjawab guru, pembelajaran dirumah menjadi tanggungjawab orang tua peserta didik, dan di lingkungan masyarakat dapat menjadi tanggungjawab orang penting yang ada di masyarakat. Setiap guru, orang tua, atauapun tokoh masyarakat haruslah menguasai, memahami, dan terampil dalam melaksanakan tugas pembelajaran tersebut (Khodijah, 2019: 177).

Hampir semua para ahli mencoba untuk mendefinisikan tentang "pembelajaran" dan sering kali pula definisi selalu berbeda dengan para ahli lainnya. Pada penjelasan ini, peneliti menggunakan beberapa definisi untuk lebih memahami pengertian dari pembelajaran. Pandangan beberapa ahli tentang pembelajaran dalam Verika (2015), yakni sebagai berikut: (1) Menurut Dwi Erna R. menyatakan bahwa pembelajaran merupakan interaksi dalam proses yang mengungkapkan bahwa ilmu pengetahuan pada pendidik dan pada peserta didik dapat menghasilkan suatu hasil dalam belajar. (2) Menurut Slavin, pembelajaran dapat diartikan bahwa perubahan perilaku seseorang 
terjadi karena orang tersebut telah memperbaiki perubahannya. (3) Menurut Woolfolk, pembelajaran dapat diberlakukan apabila pengalaman mengahsilkan suatu perubahan yang kekal dalam tingkah laku dan pengetahuan. (4) Menurut Corey menyatakan bahwa pembelajaran ialah suatu proses dimana seseorang secara sengaja mengelola lingkungannya dan bisa berkemungkinan ikut dalam perilaku seseorang secara kondisi yang spesifik. (5) Menurut Trianto pembelajaran adalah sebuah aspek kegiatan seseorang yang luas dan tidak semua mampu diuraikan. Sedangkan pembelajaran secara simple dapat dimaknai dengan kegiatan interaksi yang berkelanjutan antara pengembangan dengan pengalaman hidup. Pembelajaran dalam arti luas ialah usaha secara sadar dalam diri seorang guru untuk mengajarkan dan mendidik siswanya agar mencapai tujuan dalam pembelajaran yang diharapkan setiap guru. Kesimpulan menurut para ahli diatas adalah pembelajaran adalah suatu proses dari yang tidak paham bias menjadi paham, dari yang tidak tahu bias menjadi tahu, dan dari yang tidak mengerti bisa menjadi mengerti. Semua ini didasari dengan adanya pengalaman diri dan dapat merubah tingkah laku seseorang.

Learning strategic menurut Kemp, 1995 (dalam Rusman, 2012: 132) tidak hanya wajib dilakukan oleh para pendidik tetapi siswa siswi harus memiliki strategi dalam belajar. Hal ini dimaksudkan supaya tujuan pembelajaran diharapkan mampu menjadi lebih baik. Menurut Kemp, Dick and Carey, 1985 (dalam Rusman, 2012: 132) juga menyatahan bahwa strategi pembelajaran hendaknya dilakukan dan diterapkan oleh setiap para pendidik dan siswa siswi sehingga dapat digunakan secara bersamaan untuk mendapatkan hasil belajar yang memuaskan. Untuk menerapkan rencana pembelajaran dapat tercapai dengan baik, maka diperlukan metode yang tepat untuk dapat digunakan dalam menerapkan strategi yang sudah ditentukan. Misalnya, untuk menerapkan strategi ekspositori, maka dapat menggunakan metode ceramah, metode tanya jawab, atau diskusi. Maka dari itu, strategi merupakan ruang lingkup berbeda dan menjadi tidak tepat apabila disandingkan dengan metode. Dari hal tersebut dapat disimpulkan bahwa sebenarnya strategi lebih menunjukkan ke arah perencanaan untuk memperoleh sesuatu, sedangkan metode adalah sebuah langkah yang dapat dimanfaatkan untuk menerapkan stategi.

Menurut Joyce \& Weil (dalam Rusman, 2012: 133) untuk melakukan penyusunan model pembelajaran, para perancang dapat menggunakan prinsip pembelajaran, teori psikologis, sosiologis, analisis sistem, atau teori lainnya. Joyce \& Weil, 1980 (dalam Rusman, 2012) mencoba untuk mengelompokkan model pembelajaran atas dasar teori belajar menjadi empat model. Model tersebut dapat dijadikan sebagai perilaku pembelajaran umum untuk mencapai tujuan pembelajaran sesuai dengan keinginan. Menurut Joyce \& Weil, 1980 (dalam Rusman, 2012) model pembelajaran merupakan sebuah planning yang dapat membantu dalam proses pembentukan kurikulum, merakit persiapan pembelajaran, serta memandu dalam proses pembelajaran di kelas (Joyce \& Weil, 1980: 1). Model pembelajaran juga bisa digunakan sebagai rancangan alternatif. Maksudnya adalah para guru dapat menentukan model pembelajaran yang sesuai supaya dapat mencapai tujuan pendidikan yang efektif dan efisien.

Menurut Yamin (dalam Subroto, 2013:03) menyatakan bahwa mastery learning atau belajar tuntas adalah suatu proses pembelajaran yang dilaksanakan secara teratur, sistematis, dan terstruktur, agar proses pembelajarannya bisa membiasakan dalam pembelajaran kelompok besar, membantu dan menyelesaikan adanya perbedaan yang terjadi pada peserta didik, dan dapat meningkatkan kemampuan peserta didik dalam belajar dengan cepat. Mastery learning merupakan salah satu model pelajaran yang memfokuskan peserta didik pada penguasaan terhadap materi pembelajaran terselesaikan dengan tuntas. Menurut Kunandra (dalam Hasnah, 2011: 27) mengartikan belajar tuntas sebagai model 
pembelajaran yang menginginkan sebagian siswa dapat menguasai adanya tujuan pembelajaran secara tuntas dan menurut Kunandra belajar tuntas juga dapat diandasi oleh dua asumsi. Asumsi yang pertama yaitu teori belajar tuntas ini menyatakan bahwa hubungan antara tingkat keberhasilan peserta didik dengan kemaampuan bakat siswa siswi. Asumsi kedua, pada saat telah berlangsungnya proses pembelajaran dengan teratur, maka setiap siswa siswi dapat menguasai bahan yang telah diberikan oleh tenaga pendidik.

Belajar tuntas berpendapat dalam kondisi apapun dan semua siswa dapat belajar dengan baik dan tepat, serta mendapatkan hasil yang memuaskan untuk semua materi yang di tempuh (Mulyasa dalam Novelia, 2017:21). Sedangkan menurut Surjadi (dalam Novelia, 2017: 21) berpendapat bahwa dengan menggunakan model Mastery Learning, semua siswa siswi bisa mempelajari pelajaran dengan baik daripada sebelumnya dan bisa mendapatkan nilai yang lebih memuaskan sehingga pada saat proses pembelajaran siswa mendapatkan bimbingan agar tercapainya tujuan dalam pembelajaran.

Adapun langkah-langkah model Mastery Learning atau belajar tuntas menurut Wena (dalam Novelia, 2017:22) sebagai berikut:

a) Orientasi: dalam langkah ini, tenaga pendidik haruslah menjelaskan kepada peserta didik terkait tahapan dalam pembelajaran yang dilaksanakan di dalam kelas. Setelah menjelaskan tersebut, tenaga pendidik memberikan latihan - latihan soal yang dikerjakan oleh peserta didik selama proses pembelajaran. Setelah itu, tenaga pendidik akan memberikan pengetahuan dan penjelasan yang lebih mendalam dalam kepada peserta didik terhadap materi yang dipelajari.

b) Penyajian: dalam langkah ini, peserta didik diperbolehkan untuk bekerjasama secara berkelompok dalam menyelesaikan tugas yang diberikan oleh guru. Hal ini diharapakan dapat mendiskusikan materi yang dipelajari atau lembar kerja siswa yang telah diberikan oleh guru.

c) Latihan Terstruktur: dalam langkah ini, setiap peserta didik harus mengerjakan lembar kerja siswa (LKS) secara terstruktur sesuai dengan waktu yang diberikan atau ditetapkan oleh guru.

d) Latihan Terbimbing: dalam langkah ini, semua peserta didik mengerjakan tugas berupa lembar kerja siswa (LKS) yang telah diberikan oleh guru dan guru tersebut akan membimbing peserta didik dalam menyelesaikan tugasnya.

e) Latihan Mandiri: dalam langkah ini, peserta didik diberikan tugas atau soal tes hasil belajar untuk dikerjakan secara mandiri tanpa bimbingan guru. Kegiatan ini adalah kegiatan ujian harian agar melihat kemampuan siswa dalam memahami materi menggunakan model pembelajaran Mastery Learning.

Mata pelajaran matematika merupakan salah satu ilmu pelajaran yang memiliki peran sangat penting dalam pendidikan ataupun mengatasi beberapa permasalahan yang terjadi di dalam kehidupan sehari-hari. Sebagai contoh sederhana, apabila kita ingin mengetahui berapa total uang yang ada pada dompet kita, maka kita perlu menghitung banyaknya uang tersebut supaya kita dapat mengetahui berapa total keseluruhan uang kita yang kita miliki. Maka dari itu, sesuai dengan pendapat yang telah disebutkan oleh Skemp dalam Sholihah dan Mahmudi (2015: 176), ia menyatakan pelajaran matematika memiliki peranan yang sangat penting, tidak hanya berlaku ataupun ada di bidang pendidikan saja, melainkan dapat dijadikan sebagai alat bantu dalam ilmu bidang sains, bidang teknologi, bidang perdagangan dan bidang sebagainya.

Menurut Wittgenstein (dalam Hasratuddin, 2013: 132) matematika merupakan ilmu yang bisa mengembangkan atau meningkatkan skills seseorang untuk berpikir yang critics, logic, serta creatuve. Dengan kemampuan tersebut, maka siswa diharapkan memiliki peluang yang besar untuk menuju keberhasilan. Pernyataan tersebut 
ternyata sesuai dengan pendapat yang telah disampaikan oleh Nasional Research Concil dalam Hasratuddin (2013: 133) yang menyebutkan matematika merupakan kunci untuk menuju keberhasilan. Sehingga, apabila para siswa berhasil dalam mempelajari matematika dengan baik, maka siswa tersebut diharapkan mampu mencapai kesuksesannya dengan baik. Sedangkan menurut Russefendi dalam Iskandar (2013: 31) mengatakan bahwa pengertian dari matematika merupakan ilmu mengenai pola keteraturan dan struktur yang terorganisasi. Dan juga, menurut Russefendi dalam Ramdani (2006: 4) menyebutkan matematika tersebut merupakan sebagai hasil yang yang telah dilakukan oleh seseorang setelah dilakukan atau dilalui proses pemikiran, gagasan, dan penalaran. Menurut James \& James dalam Ramdani (2006: 4) juga mengatakan bahwa ilmu matematika merupakan bidang ilmu yang didalamnya terdapat berbagai besaran serta konsep - konsep dan memiliki hubungan antara satu dengan yang lainnya sehingga terbagi menjadi tiga bidang, yaitu aljabar, analisis, dan geometri.

Pengertian dari bangun datar merupakan sebuah gambar yang memiliki bentuk bangun dua dimensi dan mempunyai panjang dan lebar dan dibatasi oleh garis yang bentuknya lurus dan lengkung. Bangun datar juga merupakan sebuah ilustrasi yang bisa diambil dari kehidupan nyata sehingga hal tersebut tidak terlepas dari symbol. Symbol dapat digambarkan atau dituliskan secara sederhana akan tetapi mempunyai makna yang luas (Rohman, Karlimah, dan Mulyadiprana, 2017:109).

Bangun datar memiliki berbagai macam bentuk dan karakteristik tersendiri. Dalam penelitian ini, peneliti memberikan salah satu contoh bangun datar, yaitu persegi dan persegi panjang. Menurut Heruman (dalam Hidayati, 2012:21) bentuk-bentuk bangun datar yang dimiliki oleh bangun persegi dan bangun persegi panjang memiliki bentuk yang berbeda dan karakteristik yang berbeda. Hal ini dapat ditunjukkan sebagai berikut:
Persegi: sebuah bangun datar yang berbentuk segi empat dan dibatasi oleh 4 buah sisi yang sama panjang. Dalam hal ini, identik dari bangun persegi merupakan memiliki sisi dengan panjang yang sama. Berikut ini karakteristik dari bangun persegi:

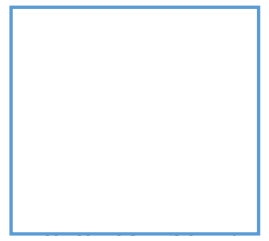

1. Bentuk keempat sudutnya siku-siku

2. Mempunyai 4 (empat) sumbu simetri

3. Diagonal-diagonal berpotongan dan membagi 2 (dua) sama panjang.

Rumus Bangun Persegi:

Luas $=$ Sisi $\mathrm{x}$ Sisi

Keliling $=$ Sisi + Sisi + Sisi + Sisi atau 4 x Sisi

Persegi Panjang: sebuah bangun datar yang berbentuk segi empat dan mempunyai 4 (empat) buah sisi, sisi-sisinya berhadapan sama panjang, sejajar, dan tegak lurus. Dalam hal ini, identik dari bangun persegi panjang merupakan sangat berbeda dengan bangun datar persegi. Hal ini dikarenakan bangun datar persegi panjang memiliki ukuran panjang dan lebar yang berbeda.

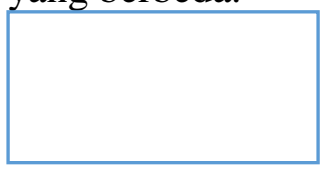

Karakteristik:

1. memiliki 4 simetri putar

2. sisi yang berhadapan, sejajar, dan sama besar

3. diagonal-diagonal membagi menjadi 2 bagian sama panjang

Rumus Persegi Panjang :

Luas $=$ Panjang $\mathrm{x}$ Lebar atau $\mathrm{P} \times \mathrm{L}$

Keliling $=$ Panjang + Lebar + Panjang + Lebar atau 2 x (Panjang + Lebar)

\section{METODE PENELITIAN}

Dalam penelitian ini, peneliti menggunakan jenis penelitian kualitatif. Hal ini dikarenakan pada metode ini, peneliti mampu menjelaskan sedalam-dalamnya terkait dengan 
pengumpulan data serta dapat mengetahui RPP, LKS dan Tes Hasil Belajar layak digunakan untuk menerapkan model pembelajaran Mastery Learning mata pelajaran Matematika materi Bangun Datar siswa kelas III. Waktu peneitian untuk pengumpulan data dibuat pada bulan Mei tahun 2020. Dan divalidatori pada bulan Juni 2020.

Instrumen yang digunakan dalam penelitian ini menggunakan metode pengumpulan data. Menurut Andriani (2014 : 5.1) mengatakan bahwa instrumen penelitian sangatlah dibutuhkan dalam sebuah penelitian karena hal tersebut merupakan sebagai alat dukung bagi para peneliti dalam menggunakan metode pengumpulan data. Maka dari itu, dalam perancangan instrumen penelitian ini harus dilakukan dengan serius dan teliti agar dalam sebuah penelitian mampu memperoleh hasil penelitian yang baik. Dalam penelitian ini, alat pengumpulan data yang digunakan dalam penelitian ini adalah lembar validasi. Ada beberapa lembar validasi yang dipakai dalam penelitian ini, yaitu: (1) Lembar Validasi Rencana Pelaksanaan Pembelajaran (RPP). (2) Lembar Validasi Lembar Kerja Siswa (LKS). (3) Lembar validasi Tes Hasil Belajar.

Setelah menentukan metode pengumpulan data yang hendak digunakan didalam sebuah penelitian, maka selanjutnya adalah peneliti menentukan teknik pengumpulan data yang digunakan untuk mengumpulkan data sehingga diharapkan mampu memperoleh sebuah data yang dibutuhkan dalam penelitian. Sesuai pendapat yang telah dikemukakan oleh Sugiono (2012: 224), ia menyebutkan bahwa teknik pengumpulan data merupakan hal paling penting dan sangat diperlukan dalam suatu penelitian karena tujuan utama dari suatu penelitian adalah memperoleh, mendapatkan, dan mengumpulkan data. Sehingga, teknik pengumpulan data yang dilakukan dalam penelitian ini yaitu peneliti menggunakan lembar validasi RPP, lembar validasi LKS, dan lembar validasi Tes Hasil Belajar. Lembar validasi dan perangkat pembelajaran tersebut akan diberikan kepada validator untuk memperoleh data yang valid. Lembar validasi dan perangkat pembelajaran akan di validatori oleh 5 orang. Dari 5 orang tersebut, peneliti menjabarkan 3 orang merupakan dosen dan 2 orang merupakan guru Sekolah Dasar.

Setelah menentukan jenis penelitian, metode pengumpulan data, dan teknik pengumpulan data, maka selanjutnya adalah menentukan analisis data. Analisis data merupakan langkah-langkah yang digunakan saat menganalisis penelitian dan mengolah data yang telah diperoleh oleh peneliti. Hal ini dilakukan karena tujuan dari analisis ini adalah untuk memperoleh dan mengetahui atas permasalahan - permasalahan yang telah dijabarkan. Sehingga, data yang dilakukan perlu dianalisis dahulu supaya dapat memberikan gambaran secara konkret dari hasil penelitian.

$$
\frac{\text { jumlah aspek yang dinilai }}{70} \times 100
$$$$
\frac{\text { jumlah aspek yang dinilai }}{50} \times 100
$$

(nilai maksimal LKS)

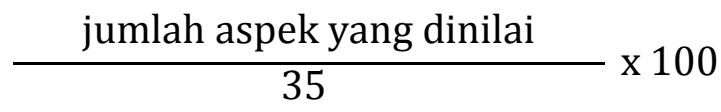

(nilai maksimal tes hasil belajar)

\section{HASIL DAN PEMBAHASAN}

Dalam penelitian ini, peneliti bermaksud untuk memperoleh jawaban atas layak tidaknya apabila dalam proses pembelajaran menggunakan salah satu model, yaitu model pembelajaran mastery learning yang diterapkan pada mata pelajaran matematika materi bangun datar siswa kelas III. Adapun hasil dari pengumpulan data mengguakan lembar validasi yang divalidator oleh 5 orang, diantaranya 3 orang merupakan dosen dan 2 orang merupakan guru Sekolah Dasar.

Adapun hasil lembar validasi yang telah di validatori oleh 3 orang dosen dan 2 orang guru. 
Tabel. Hasil lembar validasi

\begin{tabular}{|l|l|l|l|}
\hline \multirow{2}{*}{ Validator } & \multicolumn{3}{c|}{ Aspek Penilaian } \\
\cline { 2 - 4 } & RPP & LKS & $\begin{array}{l}\text { Tes Hasil } \\
\text { Belajar }\end{array}$ \\
\hline $\begin{array}{l}\text { 1. Amalia Chamidah, S.Pd., M.Pd } \\
\text { (Dosen Matematika) }\end{array}$ & 87,1 & 84 & 85,7 \\
\hline $\begin{array}{l}\text { 2. Suhartono, S.Pd.,M.Pd } \\
\text { (Dosen Matematika) }\end{array}$ & 82,8 & 80 & 82,8 \\
\hline $\begin{array}{l}\text { 3. Dra. Endang Nuryasana. M.Pd } \\
\text { (Dosen PGSD) }\end{array}$ & 84,2 & 84 & 85,7 \\
\hline $\begin{array}{l}\text { 4. Drs. Soelistijono.M. M.Pd } \\
\text { (Guru SDN Pakis VIII) }\end{array}$ & 94,2 & 94 & 94,2 \\
\hline $\begin{array}{l}\text { 5. Chyntya Ayu P.S, S.Pd.SD } \\
\text { (Guru SDN Pakis VIII) }\end{array}$ & 95,7 & 92 & 94,2 \\
\hline
\end{tabular}

Tabel 2. Kriteria Kelayakan

\begin{tabular}{|c|c|}
\hline $\begin{array}{c}\text { Kriteria } \\
\text { Validitas }\end{array}$ & Tingkat Validitas \\
\hline $81,0 \%-100,0 \%$ & Sangat Valid \\
\hline $61,0 \%-80,9 \%$ & Cukup Valid \\
\hline $41,1 \%-60,9 \%$ & Kurang Valid \\
\hline $21,0 \%-40,9 \%$ & Tidak Valid \\
\hline
\end{tabular}

\section{PENUTUP}

\section{Kesimpulan}

Berdasarkan rumusan masalah yang peneliti buat yaitu Kevalidan model pembelajaran Mastery Learning pada Mata Pelajaran Matematika Materi Bangun Datar Siswa Kelas III dan adapun tujuan dari penulisan berdasarkan rumusan masalah diatas yaitu Menyusun dan Menerapkan perangkat Model Pembelajaran Mastery Learning pada Mata Pelajaran Matematika Materi Bangun Datar. Pengumpulan data yang peneliti telah lakukan adalah menyusun perangkat dengan cara memvalidasikan perangkat seperti Rancangan Pelaksanaan Pembelajaran (RPP) beserta lembar validasi, Lembar Kerja Siswa (LKS) beserta lembar validasi, dan Tes Hasil Belajar beserta lembar validasi.

Lembar validasi tersebut yang telah peneliti buat dan divalidatori oleh 5 orang, yang terdiri dari 3 orang dosen dan 2 orang guru Sekolah Dasar (SD) ini dapat dinyatakan layak digunakan karena Rancangan Pelaksanaan Pembelajaran (RPP), Lembar Kerja Siswa (LKS), dan Tes Hasil Belajar mendapatkan nilai kelayakan yang mencapai $81,0 \%$.
Sehingga, dengan adanya hasil tersebut, maka dalam proses pembelajaran layak untuk menggunakan model pembelajaran Mastery Learning pada mata pelajaran Matematika materi bangun datar siswa kelas III.

\section{DAFTAR PUSTAKA}

[1] Andriani, Durri dkk. 2014. Metode Penelitian. Tangerang Selatan: Universitas Terbuka

[2] Hasnah, Siti.2011.Penerapan Model Pembelajaran Mastery Learning Melalui Kelompok Belajar untuk Meningkatkan Hasil Belajar Matematika Siswa Kelas VII Madrasah Tsanawiyah Muhajirin Kualu Nenas Kecamatan Tambang Kabupaten Kampar. Skripsi Tidak Diterbitkan. Pekanbaru : Universitas Islam Negeri Syarif Kasim Riau.

[3] Hasratuddin. 2008. Membangun Karakter Melalui Pembelajaran Matematika. Jurnal Pendidikan Matematika Paradikma. Vol. 6 Nomor 2.

[4] Hasratuddin. 2008. Permasalahan Pembelajaran Matematika Sekolah dan Alternatif Pemecahannya. Jurnal Matematika, FMIPA Universitas Negeri Medan. Vol. 4, No. 1

[5] Hidayati, Vinalisa. 2012. Peningkatan Kativitas dan Hasil Belajar Materi Bangun Datar Melalui Media Puzzle pada Siswa Kelas II Sekolah Dasar Negeri Kemandungan 03 Tegal. Skripsi Tidak Diterbitkan. Semarang : Universitas Negeri Semarang.

[6] Iskandar, Bayu. 2013. Peningkatan kualitas pembelajaran matematika melalui problem based learning berbantuan video pembelajaran di kelas V SDN Karangayu 02 Semarang. Skripsi Tidak Diterbitkan. Semarang : Universitas Negeri Semarang

[7] Khodijah, Nyayu.2019.Psikologi Pendidikan. Depok: PT Raja Grafindo Persada.

[8] Mahmudi, Sholihah. 2015. Keefektifan Experiental Leaning Pembelajaran Matematika MTS Materi Bangun Ruang 
Sisi Datar. Jurnal Riset Pendidikan Matematika. Vol. 2, No. 2

[9] Novelia, Rika. 2017. Penerapan Model Mastery Learning Berbantuan LKPD untuk Meningkatkan Hasil Belajar Matematika Peserta Didik di Kelas III.3 SMP Negeri 4 Kota Bengkulu. Jurnal Penelitian Pembelajaran Matematika Sekolah (JP2MS). Vol. 1, No. 1

[10] Ramadani, Yani. 2004. Kajian pemahaman Matematika Melalui Etika Pemodelan Matematika. Terakreditasi Berdasarkan Keputusan Dirjen Dikti Depdiknas Nomor : 23a/DIKTI/Kep/2004. Vol. 22, No. 1

[11]Rahmadini, Afia. 2012.Pemberdayaan Pembelajaran Materi Ajar Identifikasi Sifat-Sifat Bangun Datar Bagi Pengembangan Nilai Karakter Berpikir Kritis dan Logis. Jurnal Kreano. Vol.3. No. 1

[12]Rohman, Karlimah, Mulyadiprana, 2017. Analisis kemampuan Komunikasi Matematis Siswa Kelas III Sekolah Dasar tentang Materi Unsur dan Sifat Bangun Datar Sederhana. Jurnal Ilmiah Pendidikan Guru Sekolah Dasar. Vol. 4, No 2

[13]Rusman, 2012. Model-Model Pembelajaran. Jakarta: PT Raja Grafindo Persada

[14] Soviawati, Evi.2011. Pendekatan Matematika realistik (PMR) Untuk Meningkatkan Kemampuan Berfikir Siswa Di Tingkat Sekolah Dasar. Jurnal Khusus. No. 2

[15] Subroto, Waspodo. 2013. Penerapan Pendekatan Mastery Learning untuk Meningkatkan Hasil Belajar Siswa dalam Pembelajaran IPS Kelas IV SDN Gresik. PGSD FIP Universitas Negeri Surabaya. Vol. 1, No. 2

[16] Sugiono. 2012. Metode penelitian Kuantitatif Kualitatif dan $R \& D$. Bandung: Alfabeta

[17] Suryasubrata, Sumadi. 2012. Metode Penelitian. Jakarta: PT Raja Grafindo Persada.
[18]Syah, Muhibbin. 2010.Psikologi Pendidikan. Bandung: PT Remaja Rosdakarya.

[19] Verika, Tria. 2015. Perencanaan Pembelajaran. Jurnal pendidikan. Jakarta : Universitas Negeri Jakarta. 
HALAMAN INI SENGAJA DIKOSONGKAN 